University of Louisville

ThinkIR: The University of Louisville's Institutional Repository

$12-2010$

\title{
Functional effects of CYP1A2, NAT1, and NAT2 genetic variants in nucleotide excision repair-deficient human fibroblasts : implications for toxicological risk from environmental arylamines.
}

Carmine Simone Leggett

University of Louisville

Follow this and additional works at: https://ir.library.louisville.edu/etd

\section{Recommended Citation}

Leggett, Carmine Simone, "Functional effects of CYP1A2, NAT1, and NAT2 genetic variants in nucleotide excision repair-deficient human fibroblasts : implications for toxicological risk from environmental arylamines." (2010). Electronic Theses and Dissertations. Paper 811.

https://doi.org/10.18297/etd/811

This Master's Thesis is brought to you for free and open access by ThinkIR: The University of Louisville's Institutional Repository. It has been accepted for inclusion in Electronic Theses and Dissertations by an authorized administrator of ThinkIR: The University of Louisville's Institutional Repository. This title appears here courtesy of the author, who has retained all other copyrights. For more information, please contact thinkir@louisville.edu. 
FUNCTIONAL EFFECTS OF CYP1A2, NAT1, AND NAT2 GENETIC VARIANTS IN NUCLEOTIDE EXCISION REPAIR - DEFECIENT HUMAN FIBROBLASTS: IMPLICATIONS FOR TOXICOLOGICAL RISK FROM ENVIRONMENTAL ARYLAMINES

By

Carmine Simone Leggett

B.S., Spelman College, 2006

M.S., Delaware State University, 2008

\begin{abstract}
A Thesis
Submitted to the Faculty of the

Graduate School of the University of Louisville

in Partial Fulfillment of the Requirements

for the Degree of
\end{abstract}

Master of Science

Department of Pharmacology and Toxicology

University of Louisville School of Medicine

Louisville, Kentucky

December 2010 

FUNCTIONAL EFFECTS OF CYP1A2, NAT1, AND NAT2 GENETIC VARIANTS IN NUCLEOTIDE EXCISION REPAIR - DEFECIENT HUMAN FIBROBLASTS:

IMPLICATIONS FOR TOXICOLOGICAL RISK FROM ENVIRONMENTAL ARYLAMINES

By

Carmine Simone Leggett

B.S., Spelman College, 2006

M.S., Delaware State University, 2008

A Thesis Approved on

August 6, 2010

by the following Thesis Committee:

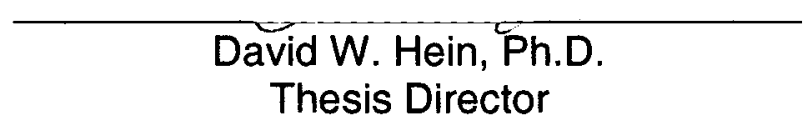
Thesis Director

Rameșh G Gupta. Ph.D.

Kenneth E. Palmer, Ph.D.

J. Christopher States, Ph.D.

John O. Trent, Ph.D. 


\section{DEDICATION}

This thesis is dedicated to my parents Mr. Johnny L. Leggett and Mrs. Connie M. Leggett whose prayers and words of encouragement blessed me with the tenacity to persevere despite obstacles and disappointments. 


\section{ACKNOWLEDGEMENTS}

I would like to thank Dr. David W. Hein for his guidance, patience, and belief in my ability to succeed. I would like to thank my valued committee members Drs. Ramesh Gupta, Kenneth Palmer, J. Christopher States, and John Trent for their assistance and scientific contributions. I would also like to express my overwhelming gratitude to my family, friends, and mentors for their undying support throughout my educational pursuit and professional endeavors. 


\begin{abstract}
FUNCTIONAL EFFECTS OF CYP1A2, NAT1, AND NAT2 GENETIC VARIANTS IN NUCLEOTIDE EXCISION REPAIR - DEFECIENT HUMAN FIBROBLASTS: IMPLICATIONS FOR TOXICOLOGICAL RISK FROM ENVIRONMENTAL ARYLAMINES
\end{abstract}

Carmine S. Leggett

August 6, 2010

Arylamine $\mathrm{N}$-acetyltransferase 1 (NAT1) and 2 (NAT2) catalyze the detoxification and/or activation of aromatic and heterocyclic amine carcinogens by two pathways. This metabolism reaction can lead to the detoxification by $\mathrm{N}$ acetylation, or bioactivation by O-acetylation often preceded by CYP450 hydroxylation. Human NAT2 polymorphisms are characterized by rapid, intermediate, and slow acetylator phenotypes, thus resulting in differences in the rate of arylamine metabolism and consequently cancer risk. We have constructed nucleotide excision repair-deficient human cell model expressing human CYP1A2 and human NAT1and NAT2 in order to investigate carcinogen metabolism and cancer susceptibility in human cells.

In this study we introduce the utilization of SV40-transformed human fibroblasts (GM4429) to examine the functional effects of human NAT2 haplotypes, in the presence of human NAT1. Many carcinogens, such as 4aminobiphenyl, are metabolized by both NAT1 and NAT2, consequently both isozymes have toxicologically significant functions in the metabolism of 
arylamines. Furthermore, both NAT1 and NAT2 isozymes are expressed in human liver, where they are significant to carcinogen detoxification and/or activation consequences. With this model, we can examine the role of NAT1 and NAT2 carcinogen metabolism and genotoxicity in a NER-deficient human cell.

In this study, we investigate novel inhibitors of NAT1 and NAT2. Previous studies have identified approximately 150 NAT inhibitor candidates following computer-based in silico screening of approximately 20 million compounds. The inhibitory properties of these compounds were tested using a High Performance Liquid Chromatography assay specific for human NAT1 and NAT2. A novel compound was identified that is an effective inhibitor of NAT1 (100\%) and NAT2 (90\%). This inhibitor was selective for NAT1 $\left(\mathrm{IC}_{50}\right.$ about $\left.1 \mu \mathrm{M}\right)$, compared to an $\mathrm{IC}_{50}$ of $82.2 \mu \mathrm{M}(\mathrm{SMZ})$ for NAT2. Further studies will determine potency and efficacy of NAT inhibitors to reduce DNA adduct formation and mutagenesis. We have also successfully constructed and characterized NER-deficient human fibroblast cells with stable expression of human NAT2 alleles (NAT2*4, NAT2*5B, or NAT 2*7B) and CYP1A2. These models are used to better understand the effects of NAT2 haplotypes on carcinogen metabolism and DNA adduct formation in human cells. 
TABLE OF CONTENTS

PAGE

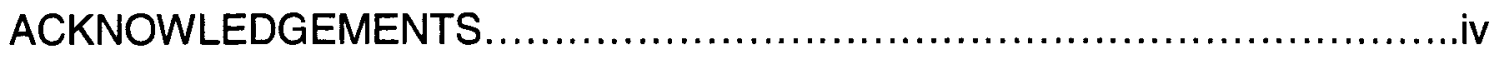

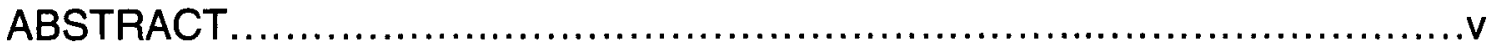

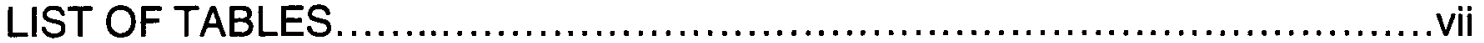

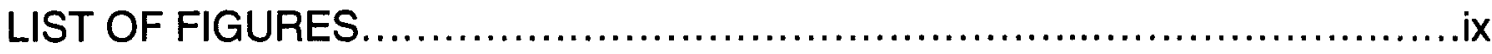

CHAPTER

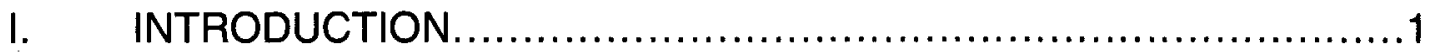

II. SPECIFIC AIMS ......................................................

III. METHODS AND MATERIALS .....................................14

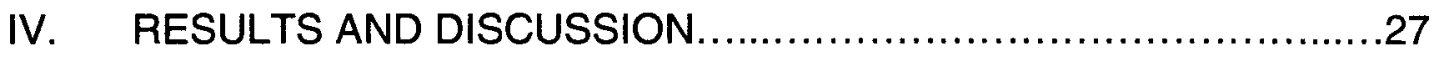

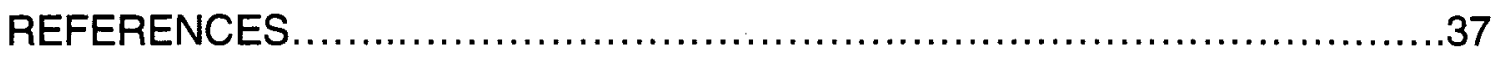

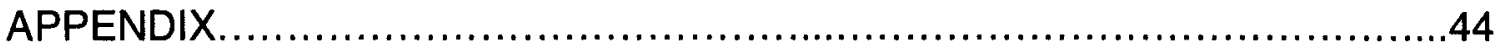

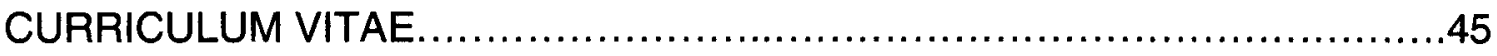




\section{LIST OF TABLES}

TABLE

PAGE

1. Percent Inhibition of Screened Compounds ....................................46 


\section{LIST OF FIGURES}

FIGURE

PAGE

1. Metabolic pathways of 4 -aminobiphenyl by NAT ...............................31

2. Schematic of stable transfection using the Invitrogen Flp-In System............32

3. 7-ethoxyresorufin-O-deethylase (EROD) activity ............................33

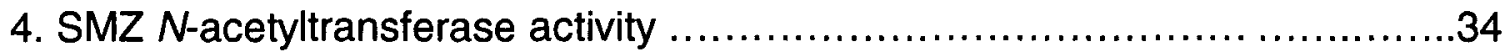

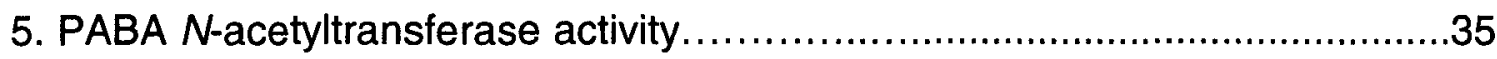

6. Compound 10 inhibition of PABA and ABP $\mathrm{N}$-acetylation activity...............36

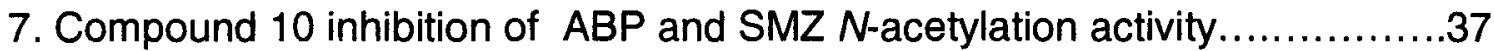

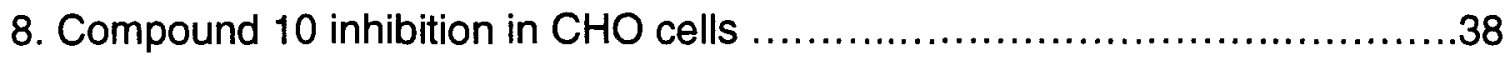




\section{CHAPTER I \\ INTRODUCTION}

Susceptibility to chronic diseases, such as cancer, involves interactions between genetic variants of xenobiotic-metabolizing enzymes (XMEs) and the environment. However the effects of genetic variance on toxicological risk are not fully understood. Many environmental arylamine genotoxins are metabolized by arylamine $\mathrm{N}$-acetyltransferases (NATs). The two isozymes, arylamine $\mathrm{N}$ acetyltransferases 1 (NAT1) and 2 (NAT2), catalyze the detoxification and/or activation of aromatic and heterocyclic amines (Hein et al., 2000). These metabolic pathways can lead to the detoxification by $\mathrm{N}$-acetylation, or bioactivation by $\mathrm{O}$-acetylation, preceded by cytochrome $\mathrm{P} 450$ hydroxylation (Agudo et al 2009). The arylamine acetoxy products are capable of forming electrophilic species that covalently bind to DNA and proteins, thus causing DNA adduct formation (Figure 1.) and other toxicological insults.

NAT polymorphisms were first discovered after differences in toxicity were seen in patients treated with isoniazid for tuberculosis (Hein et al., 2000). These differences were attributed to single nucleotide polymorphisms (SNPS) in the NAT2 gene. Human NAT2 polymorphisms are characterized by rapid, intermediate, and slow acetylator phenotypes, thus resulting in differences in the rate of arylamine metabolism and consequently toxicological risk (Hein, 2009). 
This family of enzymes has been studied for their functional roles in pharmacogenetics and toxicological susceptibility.

NAT1 and NAT2 genotypes may play an important role in cancer risk (Hein et al., 2000). Previous studies in our laboratory investigated the effects of NAT2 genetic variants on 2-amino-1-methyl-6-phenylimidazo[4,5b]pyridine (PhIP) induced DNA adduct formation and mutagenesis in nucleotide excision repair (NER) -deficient Chinese hamster ovary $(\mathrm{CHO})$ cells that recombinantly express human CYP1A2 and human NAT2*4 or NAT2*5B alleles (Metry et al., 2007). This study provides evidence in support of the ability to study mutagenesis and DNA damage in a cell line stably transfected with human NAT2 and human CYP1A2. Our study will investigate the functional effects of altered enzymatic activity in CYP1A2 and NAT1 and genetic variants in the NAT2 gene on oxidative stress, DNA adduct formation and mutagenesis by exploiting the use of NER deficient Simian Virus 40 (SV40) - transformed human fibroblast (GM4429).

The utilization of SV40-transformed human fibroblasts to examine the functional effects of human NAT2 haplotypes in the presence of human NAT1 is a novel concept. Human fibroblast endogenously express NAT1, unlike any other cell model previously used. These cells have a deficiency in NER which inhibits the repair of bulky DNA lesions induced by UV or aromatic and heterocyclic amine genotoxins. The ability of this cell line to form bulky DNA lesions is pertinent to our study. GM4429 cells were derived from a Caucasian Xeroderma Pigmentosum (XP) patient exhibiting a delayed onset of neurological disease. These cells are widely used to study NER deficiency due to their variant 
complementation group A (XP-A) (States et al., 1996). Simian Virus 40, an oncogenic DNA virus, induces malignant transformation and cause a loss of cell cycle checkpoint control (States et al., 1996). The large T-antigen of the SV40 virus accomplishes abrogation of the cell cycle checkpoint by sequestering p53 which stops both G1 and G2 checkpoints (States et al., 2002). The use of this cell line to study NAT metabolism and genetic variance is an innovative and exciting addition to the previously used Chinese hamster ovary cell (Metry et al, 2007), COS-1 cell (Zang et al., 2007), yeast (Fretland et al., 2001), and E. Coli (Hein et al., 1994) models. We are able to utilize this cell line to study functional characterization of human CYP1A2, human NAT1 and human NAT2 phenotypic behavior in cells expressing these enzymes and genetic variants which is important to better understand the relationship between risk and genetic variance. Studies have indicated that synergistic effects caused by gene-gene interactions have been noted in increased risk to certain cancers (Cascorbi et al., 2001, Sanderson et al., 2007, and Taylor et al., 1998), further illustrating that the use of these cell lines expressing both human NAT isozymes and human CYP1A2 is beneficial for functional genomic studies of NAT and cancer risk. We believe the NER-deficient SV40-transformed human fibroblast cell lines will advance the study of NAT2 genetic variation and its effect on toxicological risk.

Humans are exposed to many aromatic and heterocyclic amine environmental genotoxins that pose a risk upon metabolism. These risks include, but are not limited to, oxidative DNA damage, DNA adduct formation, and mutagenesis. NAT enzymes are recognized for their ability to metabolize 
carcinogens and arylamine genotoxins such as 4-aminobiphenyl (ABP), 2aminofluorene (AF), 2,6-dimethylaniline (2,6-DMA), 3,5-dimethylaniline (3,5DMA), and 3-ethylaniline (3-EA). Carcinogens ABP and AF are metabolized by both NATs, illustrating that both NAT1 and NAT2 have an important role in the metabolism of arylamines (Grant et al., 1990). Exposure to ABP, which is present in tobacco smoke, has been associated with bladder cancer risk (Liu et al., 2008). AF, whose $\mathrm{N}$-acetylated derivative was developed as an insecticide, is associated with mutagenesis (Sugamori et al., 2006). Although some arylamine substrates such as ABP and AF are metabolized by both NAT1 and NAT2, each of the NATs exhibit specificity (Liu et al., 2007). Studies show that when the relative capacities of human NAT1 and NAT2 to catalyze the metabolic activation of $\mathrm{N}$-hydroxy-2-aminofluorene and $\mathrm{N}$-hydroxy-4-aminobiphenyl were assessed, the rates were higher for NAT1 than NAT2 with both substrates (Hein et al., 1993). Capacities of human NAT1 to catalyze the metabolic activation of $N$ hydroxy-2-acetylaminofluorene and $\mathrm{N}$-hydroxy-4-acetylaminobiphenyl via $\mathrm{N}, \mathrm{O}$ acetylation were lower than the metabolic rates of $N$-hydroxy-2-aminofluorene and $\mathrm{N}$-hydroxy- 4-aminobiphenyl via $\mathrm{O}$ - acetylation (Hein et al., 1993).

Arylamine genotoxins 2,6-DMA and 3,5-DMA are present in cigarette smoke and pollution from industrial sources. The alkylanilines, 2,6-DMA ,3,5-DMA, and 3-EA, are associated with bladder cancer among the general population including non-smokers (Gan et al., 2004). Exposure to these alkylanilines (monocyclic arylamines) is of particular interest to toxicological risk studies because of the high distribution of these compounds in the environment. Monocyclic arylamines 
2,6-DMA , 3,5-DMA, and 3-EA are distributed widely in the environment, resulting in ubiquitous exposure (Skipper et al., 2010). Since these compounds are present in cigarette smoke, indoor spaces contaminated with cigarette smoke exhibit higher levels of alkylanilines than in uncontaminated spaces. Industrial sources also provide significant levels of exposure to these compounds (Skipper et al., 2010). It is important to note that in previous studies conducted in Italy, 2,6-DMA levels were higher among non-smokers than smokers warranting the conclusion that the environmental significance of monocyclic arylamine exposure is extensive and is not confined to groups such as active smokers or those subjected to occupational exposure (Skipper et al.,2010). Studies have indicated that diverse arylamine exposures are strongly associated with bladder cancer risk among nonsmokers (Gan et al., 2004). This suggests that environmental exposure is as important as active smoking exposure. The 5 arylamine compounds used in this study were chosen because of their possible impact on toxicological risk by NAT metabolism.

It is thought that monocyclic arylamines, to which humans are exposed, impose toxicological risk upon bioactivation by NATs. The activation of these compounds by metabolic hydroxylation by CYP and/or O-acetylation by NAT leads to the production of toxic $\mathrm{N}$-arylhydroxyamines and $\mathrm{N}$-acetoxyarylamines (Liu et al., 2007). These compounds are also $\mathrm{N}$-acetylated by NAT which is considered the detoxification reaction. The $\mathrm{N}$-acetylation reaction decreases substrate availability for metabolic hydroxylation of the primary amino group (Liu et al., 2007). 
NAT1 and NAT2 have $87 \%$ nucleotide homology in the coding region, and despite their high protein homology, they differ in substrate specificity (Butcher et al., 1999). The substrate affinity for NAT1 or NAT2 will play a major role in arylamine metabolism and toxicological risk, therefore the affinity of the above mentioned arylamine genotoxins for NAT1 or NAT2 will be determined. They also exhibit differences in tissue distribution. Human NAT2 is expressed mainly in the liver and intestine, while human NAT1 has a widespread tissue distribution in adult tissues, including the liver (Russell et al., 2009). Moreover, they are both significant to carcinogen detoxification and/or activation consequences.

Oxidative DNA damage is an important toxicological response to arylamine genotoxin metabolism (Murata et al., 2001). Its implications have been noted in teratogenesis and neurodevelopmental deficits (Wells et al., 2010), pathological eye conditions, such as age dependent cataract formation (Dairou et al., 2005), chronic hepatitis, Fanconi's anemia, diabetes mellitus and Helicobacter pylori infections (Lodovici et al., 2000). Furthermore oxidative DNA damage is known as a risk factor for many diseases including many cancers such as breast cancer (Sova et al., 2010), renal cell carcinoma and squamous cell carcinoma (Tanaka et al., 2000). Reactive oxygen species (ROS) are produced by the metabolism of environmental arylamine genotoxins such as chemical carcinogens and environmental agents (Kim et al., 2003). ROS can lead to deleterious and extensive DNA damage including single strand breaks and DNA adduct formation. Modified bases such as 8-hydroxy-deoxyguanosine $(8-\mathrm{OH}$ - 
dG) can be used as a marker to evaluate DNA damage caused by oxidative stress (Kim et al., 2003).

Oxidative stress has also been noted for its ability to regulate NAT1 activity. Reactive oxygen species, such as $\mathrm{H}_{2} \mathrm{O}_{2}$ at physiological concentrations, can reversibly inactivate the NAT1 enzyme due to oxidation of the catalytic cysteine residue in the active site (Rodrigues - Lima et al., 2004). This change in NAT1 enzymatic activity and function results in differences in potential toxicological consequences, further demonstrating the importance of understanding the relationship between oxidative damage following NAT metabolism and toxicological response. In this study we will utilize cell lines that express NAT2 alleles $\left(N A T 2^{\star} 4, N A T 2^{\star} 5 \mathrm{~B}\right.$, and NAT2*7B) and combinations of shRNA-lowered NAT1 and CYP1A2 enzymatic activity to assess how these changes affect levels of oxidative stress, DNA adduct formation, and mutagenesis following exposure of human cells to arylamines.

In order to elucidate ways to reduce or ablate toxicological risk caused by arylamine genotoxin metabolism, we will employ the use of a small molecule inhibitor. Studies provide evidence that NAT inhibitors have been beneficial in investigating the catalytic mechanism of NATs and are emerging as drug targets (Russell et al., 2009). Other studies explore NAT inhibitors as a means to alter biotransformation by NAT, consequently providing potential differences in toxicological consequences (Dairou et al., 2009). Our study introduces the use of novel and effective inhibitors of NAT1 to reduce levels of DNA adduct formation and mutagenesis. The selectivity of NAT1 inhibitors may be explained 
by the NAT1 catalytic pocket comparison to that of NAT2. Both NATs possess a functional Cys-His-Asp catalytic triad that allows the transfer of an acetyl group for acetyl-coenzyme $\mathrm{A}$ in a ping-pong bi-bi reaction mechanism followed by acetyl group transfer to a substrate (Hein, 2009). The NAT1 catalytic pocket is $40 \%$ smaller than that of NAT2; this alludes to catalytic pocket size influence on substrate specificity. Substrate selectivity is also strongly influenced by three key active site loop residues $\mathrm{F} 125, \mathrm{Y} 127$, and $\mathrm{R} 129$, determined by site-directed mutagenesis of individual amino acids (Goodfellow et al., 2000).

There have been many reported associations between NAT1 genetic polymorphisms and increased risk of carcinogenesis by molecular epidemiological studies. NAT1 polymorphisms have been associated with individual risk to urinary bladder, colorectal, breast, lung, prostate, and pancreatic cancer (Walraven et al., 2008). The close association between NAT1 polymorphisms and risk for so many diseases indicates the potential clinical benefits of NAT1 inhibition. For example, in comparison with all other NAT1 genotypes the putative rapid acetylator genotype $\left(N A T 1^{*} 10\right)$ was significantly higher in prostate cancer cases than in controls (Hein et al., 2002). NAT1, which is present in most extrahepatic tissues, facilitates the activation of many carcinogens and arylamines by O-acetylation associating NAT1 with certain cancers (Hein, 2002). Taken together, this suggests that inhibition of NAT1 may be beneficial in reducing toxicological risk resulting from the activation of carcinogens and genotoxins by NAT1 $O$-acetylation. 
The human NAT1 and NAT2 isozymes are similar in structure; therefore inhibition of NAT2 may be of concern considering the ability of NAT2 to metabolize many pharmaceutical agents. One may suspect that inhibition of NAT2 may lead to drug toxicity because NAT2 will be unable to facilitate the detoxification of its pharmaceutical targets. To address this concern, if the selective inhibitor is used as a drug, we are proposing overcoming this caveat by the use of site-directed administration of the potential inhibitor to extrahepatic target organs where NAT2 is not expressed. This will allow us to not only validate a NAT1 inhibitor as a tool to study NAT1 mechanistically, but to validate the potential use of the inhibitor as a drug to reduce NAT1 associated risk. Since NATs activate arylamine genotoxins to induce oxidative stress, DNA adduct formation, and mutagenesis, we will explore applications to reduce this risk with the use of a NAT1 inhibitor. 


\section{CHAPTER II}

\section{SPECIFIC AIMS}

The study of genetic variation in xenobiotic-metabolizing enzymes, such as arylamine N-acetyltransferases (NATs) and cytochrome P450s (CYPs) bestows an essential contribution to the understanding of consequences resulting from toxicological insult (e.g. oxidative stress, DNA adducts formation and mutagenesis). Functional genomic studies help to better understand relationships between genetic variation and toxicological risk. It is our objective to study the effects of NAT2 genetic variants and altered enzymatic activity in xenobioticmetabolizing enzymes (NAT1 and CYP) on oxidative stress, DNA adduct formation, and mutagenesis, by exploiting the use of nucleotide excision repair (NER) deficient SV40-transformed human fibroblast cells. We hypothesize that xenobiotic-metabolizing enzyme phenotypes (i.e., rapid or slow) associated with allelic variants (e.g. NAT2*4, NAT2*5B, NAT2*7B) will impact levels of oxidative stress, DNA adduct formation, and mutagenesis. To test this hypothesis, we propose the following specific aims:

Aim 1: To construct and to characterize NER-deficient SV40-tranformed human fibroblast cell lines that recombinantly express human CYP1A2 and human NAT2 alleles $N A T 2{ }^{*} 4, N A T 2^{*} 5 B$, or $N A T 2^{*} 7 \mathrm{~B}$. We hypothesize that alleles $N A T 2^{*} 5 B$ and NAT2*7B will exhibit differences in anylamine metabolism as compared to the reference allele NAT2*4. Previous studies successfully use a NER-deficient 
Chinese hamster ovary (CHO) cell model expressing human CYP1A2 and human NAT2 to investigate the effects of NAT2 genetic variants on carcinogen induced DNA adduct formation (Metry et al., 2007). In this study we introduce the utilization of SV40-transformed human fibroblasts (GM4429) to examine the functional effects of human NAT2 haplotypes on arylamine metabolism and toxicological risk. The construction of these cell lines will be accomplished using the Flp-In System (Invitrogen, Carlsbad, CA). We will complete the characterization by including the use of functional assays to evaluate CYP activity (ethoxyresorufin-o-deethylase (EROD) assay), NAT1 protein expression (Western blot assay), $\mathrm{N}$ - and $\mathrm{O}$ - acetylation activity in vitro (high-performance liquid chromatography (HPLC); substrates: p-aminobenzoic acid (PABA), Sulfamethazine (SMZ), 4-aminobiphenyl (ABP) , 2,6-dimethylaniline (2,6-DMA), 3,5-dimethylaniline (3,5-DMA), and 3-ethylaniline (3-EA), $\mathrm{N}$-acetylation activity in situ, and NAT mRNA expression (Taqman assay). In addition, the genotype of NAT1 (Taqman assay) and CYP1A2 (sequencing) will be determined. We will also determine the affinity of arylamine genotoxins for NAT1 and/or NAT2 using kinetic studies $\left(K_{m}, V_{\max }\right)$ for each arylamine listed above.

Aim 2: To evaluate and to compare the effects of combinations of genetic variants in NAT2 (i.e. rapid or slow phenotypes) and high and low NAT1 and CYP1A2 enzymatic activities on oxidative stress, DNA adduct formation, and mutagenesis. We hypothesize that cell lines with combinations of altered enzymatic activity associated with slow acetylator (NAT) and rapid hydroxylation (CYP) will present an increased incidence of oxidative DNA damage, while cell 
lines with rapid acetylator (NAT) and slow hydroxylation (CYP) will exhibit less oxidative DNA damage, but increased incidences of DNA adduct formation and mutagenesis. It has been reported that the $N$-hydroxy derivatives of arylamine genotoxins have the ability to cause oxidative stress (Murata et al., 2001). We will investigate oxidative stress in cell lines constructed in Aim 1, by measuring oxidized DNA, 8-hydroxy-2-deoxyguanosine (8-OH-dG), by Enzyme Linked Immunosorbent Assay (ELISA; Cayman Chemicals). We will utilize shRNA plasmids (SABiosciences) to achieve combinations of high or low enzymatic activity by significant gene knockdown of endogenous human NAT1 and/or stably transfected human CYP1A2. As noted in Aim 1, human NAT2 (NAT2*4, $N A T 2^{\star} 5 \mathrm{~B}$, and $N A T 2^{\star} 7 \mathrm{~B}$ ) will be stably transfected in these cells allowing the achievement of combinations with rapid and slow NAT2 phenotypes. Enzymatic activity will be measured using functional assays specific for NAT1 and NAT2 (HPLC) and CYP1A2 (EROD assay) to validate phenotypic behavior after shRNA knockdown. We will measure DNA adduct formation by HPLC-tandem mass spectrometry (LC-MS-MS) technology and mutagenesis by assays for mutagenesis at the hypoxanthine-guanine phosphoribosyltransferase (hrpt) locus.

Aim 3: To determine the effectiveness of a novel arylamine NAT1 small molecule inhibitors on reducing mutagenesis and DNA adduct formation. We hypothesize that the inhibition of NAT1 enzymatic activity will reduce mutagenesis and DNA adduct formation, but increase oxidative DNA damage. The inhibitory properties of compounds were tested using an enzymatic assay (HPLC) specific for human 
NAT1 and NAT2. A compound was identified that is an effective inhibitor of NAT1. This inhibitor was also selective for NAT1. This study will determine potency and efficacy of this compound to reduce mutagenesis and DNA adduct formation in NER SV40-transformed human fibroblasts treated with compounds that have an affinity for NAT1. Additional compounds are currently being screened for their ability to inhibit NAT, after which their potency and efficacy to reduce toxicological risk will be evaluated. 
CHAPTER III

\section{METHODS AND MATERIALS}

Aim 1: To construct and characterize NER-deficient SV40-tranformed human fibroblast cell lines that recombinantly express human CYP1A2 and human NAT2 alleles $N A T 2^{\star} 4, N A T 2^{\star} 5 \mathrm{~B}$, or $N A T 2^{\star} 7 \mathrm{~B}$. We hypothesize that alleles $N A T 2{ }^{*} 5 B$ and NAT2*7B will exhibit differences in arylamine metabolism as compared to the reference allele NAT2*4.

Stable Transfection and Cell Culture

We will construct stably transfected NER-deficient SV40-transformed human fibroblasts that express human CYP1A2 and NAT2 alleles (NAT2*4, NAT2*5B, or NAT2*7B) using the Flp-In system (Invitrogen) as described previously in $\mathrm{CHO}$ cells by Metry et al., (2007). NER-deficient SV40-transformed human fibroblasts (GM4429) were chosen because they endogenously express NAT1, they are immortalized by the SV40 oncogenic virus, and they poorly repair arylamineinduced DNA adducts. The pFRT/lacZeo plasmid will be transfected into the NER-deficient GM4429 cell, resulting in a single integrated FRT site. Cells will be split $24 \mathrm{hr}$ after transfection and treated with medium supplemented with Zeocin $(200 \mu \mathrm{g} / \mathrm{mL}) 48 \mathrm{hr}$ after transfection, for selection according to the manufacturer's protocol. Zeocin - resistant clones will be picked with cloning cylinders. The cell lines with a single intergrated FRT site determined by real- 
time polymerase chain reaction (PCR) and Southern blot screening will be selected for additional transfection. The pIRES plasmid containing cDNAs of human CYP1A2 and NADPH-cytochrome P450 reductase gene, will be transfected into the newly constructed GM4429-FRT cell line using Effectene Transfecton Reagent kit (Qiagen). Geneticin -resistant clones will be picked using cloning cylinders. Human NAT2 alleles (NAT2*4, NAT2*5B, or NAT2*7B) will be transfected using the pcDNA5/FRT plasmid and co-transfected with pOG44, a Flp recombinase expression plasmid, into GM4429-FRT-CYP1A2 cells (Figure 2.). Stably transfected cells will be selected by geneticin and hygromycin resistance. Cells will be grown in alpha-modified minimal essential medium (aMEM) supplemented with L-glutamine, 10\% fetal bovine serum, 100 units $/ \mathrm{mL}$ of penicillin, and 100 units $/ \mathrm{mL}$ streptomycin; incubated at $37^{\circ} \mathrm{C}$ in $5 \% \mathrm{CO}_{2}$. Medium will be supplemented with selective agents (hygromycin and geneticin) to ensure maintenance of the stable transfection.

\section{Cytochrome P450 (CYP1A2) Activity}

Different clones will express different levels of CYP1A2 catalytic activity. To ensure that all cell lines have comparable CYP1A2 enzymatic activity whole cell samples will be assayed for 7-ethoxyresorufin oxidation activity by fluorimetric determination as described by Bendaly et al., (2007). This reaction will be conducted in a 96-well plate, containing 1 million cells in $10 \mu$ of PBS with $5 \mathrm{mM}$ glucose and $5 \mu \mathrm{M} 7$-ethoxyresorufin. The reaction will be incubated at $37^{\circ} \mathrm{C}$ for 10 minutes. Resorufin formation will be measured by fluorescence at emission 
wavelength $585 \mathrm{~nm}$ and excitation wavelength of $530 \mathrm{~nm}$. Cell lines from clones exhibiting 7-ethoxyresorufin oxidation activity comparable to the parent cell line (GM4429) will be utilized for further characterization and study.

\section{NAT Protein Expression (Western Blot Assay)}

NAT1 protein expression will be evaluated using western blot assays as described by Stanley et al., (1996). Approximately $20 \mu \mathrm{g}$ of cell lysate will be mixed with $2 x$ loading buffer, boiled for $5 \mathrm{~min}$, and resolved by $12 \%$ SDS-PAGE gel and then transferred by semi-dry electroblotting to polyvinylidene fluoride (PVDF) membrane. The membrane will be probed with the primary polyclonal antibody ES195 (1:1000, provided by Edith Sim, University of Oxford, UK) and the HRP-conjugated secondary mouse anti-rabbit IgG antibody $(1: 10,000$, provided by Pierce Protein Research Products, Rockford, IL.). ECL plus chemiluminescence will be used to detect the signal (Amersham Biosciences, Piscataway, NJ).

\section{$\underline{N \text {-acetylation Activity (in vitro) }}$}

$\mathrm{N}$-acetylation of PABA, SMZ, and selected arylamine genotoxins (2,6-DMA, 3,5-

DMA, 3-EA) will be evaluated in vitro using reverse phase high performance liquid chromatography (HPLC) (Fretland et al., 2001). Reactions will be prepared with acetyl- coenzyme $A(300 \mu \mathrm{M})$, selective substrates $(300 \mu \mathrm{M})$ p-aminobenzoic acid (NAT1), sulphamethazine (NAT2), or selected arylamine genotoxins, and incubated at $37^{\circ} \mathrm{C}$. Reactions will be stopped using $1 \mathrm{M}$ acetic acid and protein 
centrifuged at $10,000 \mathrm{xg}$ for 10 minutes. Reaction products in the resulting supernatant will be separated by reverse-phase HPLC. HPLC separation for sulphamethazine NAT2 assays will be achieved on a C18 LiChrospher $^{\circledR}$ $125 \times 4 \mathrm{~mm}$ column using a gradient $91: 9$ sodium perchlorate $(\mathrm{pH} 2.5) /$ acetonitrile to $71: 29$ sodium perchlorate $(\mathrm{pH} 2.5)$ / acetonitrile over $5 \mathrm{~min}$ at $260 \mathrm{~nm}$. HPLC separation for p-aminobenzoic acid NAT1 reactions will be achieved using a gradient 96:4 sodium perchlorate $(\mathrm{pH} 2.5) / 88: 11$ acetonitrile at $280 \mathrm{~nm}$. HPLC separation for 2,6-DMA, 3,5-DMA, and 3-EA will be achieved using a gradient 50:50 acetonitrile and $0.01 \mathrm{M}$ potassium phosphate buffer $(\mathrm{pH} 5)$ at $1 \mathrm{ml} / \mathrm{min}$ at $210 \mathrm{~nm}$ (Martin et al., 1996).

\section{O-acetylation Activity (in vitro)}

O-acetylation catalytic activity will be evaluated using reverse phase HPLC instrumentation as described above. Reactions will be carried out as described by Bendaly et al., (2007). Briefly, reaction mixtures containing cell lysate, 1 $\mathrm{mg} / \mathrm{ml}$ deoxyguanosine, substrate $(100 \mu \mathrm{M} \mathrm{N}$-hydroxy-ABP) and $(300 \mu \mathrm{M})$ acetyl coenzyme $A$ will be incubated at $37^{\circ} \mathrm{C}$ and stopped with ethyl acetate. Reactions will be centrifuged for 10 minutes and the organic phase will be transferred, allowed to dry, and re-suspended in $100 \mu \mathrm{M}$ of $10 \%$ acetonitrile. HPLC separation will be achieved using a gradient of $50: 50$ sodium perchlorate $(\mathrm{pH}$ 2.5)/ acetonitrile over 3 minutes to $80: 20$ sodium perchlorate $(\mathrm{pH} 2.5)$ /acetonitrile over 2 minutes at a wavelength of $300 \mathrm{~nm}$. Measurements will be adjusted according to baseline measurements using lysates of GM4429/CYP1A2 cell line. 


\section{$\underline{N \text {-acetylation Activity (in situ) }}$}

$\mathrm{N}$-acetylation activity in situ will measured in whole cell samples. Human fibroblast cell lines, grown to confluency, will be treated with medium supplemented with PABA, SMZ, ABP, AF, 2,6-DMA, 3,5-DMA, and 3-EA in varying doses including 10,50 , and $300 \mu \mathrm{M}$. Medium will be collected at various time points $(2,6,8,10 \mathrm{~h})$. Existing protein will be precipitated out of solution using $1 \mathrm{mM}$ acetic acid; the reaction products and substrates will be subjected to HPLC for separation. Measurement of acetylated PABA, SMZ, ABP, AF, 2,6-DMA, 3,5DMA, and 3-EA will be carried out as described above.

\section{Kinetic Studies}

We will measure kinetic parameters $K_{m}$ and $V_{\max }$ of acetyl CoA and arylamine genotoxins such as 2,6-dimethylaniline (2,6-DMA), 3, 5-dimethylaniline (3,5DMA), and 3-ethylaniline (3-EA) for NAT1 or NAT2. We will determine acetyl CoA $K_{m}$ and $V_{\max }$ with varying acetyl CoA concentrations (0- $\left.400 \mu \mathrm{M}\right)$ and fixed substrate concentrations $(300 \mu \mathrm{M})$. The substrate $K_{m}$ and $V_{\max }$ will be determined with varying substrate concentrations $(0-1 \mathrm{mM})$ and a fixed acetyl CoA concentration of $100 \mu \mathrm{M}$. The apparent $K_{m}$ and $V_{\max }$ constants will be calculated using linear regression of Eadie-Hoftsee plots. These values (apparent $K_{m}$ and $V_{\max }$ ) will allow us to select arylamines for further study based on arylamine affinity for either NAT1 or NAT2. 


\section{NAT mRNA expression (Tagman Quantitative RT-PCR Assays)}

TaqMan assays will be used to assess level of NAT1 and NAT2 mRNA expressed in each cell line. TaqMan Universal Master Mix (Applied Biosystems, Foster City, California, USA), primers and probes, 96 well optical plates and caps will be used. Synthesis of first strand cDNA will be carried out using Superscript III ReverseTranscriptase (Invitrogen) following the manufacturer's protocol using $1 \mu \mathrm{g}$ of DNase-treated total RNA. PCR with $1 \mathrm{x}$ final concentration of TaqMan Universal Master Mix, $300 \mathrm{nM}$ of each primer and $100 \mathrm{nM}$ of probe in $20 \mu \mathrm{l}$ will be performed using Applied Biosystems StepOnePlus Real-Time PCR Systems (Applied Biosystems). For quantitative RT-PCR of NAT1 (Husain et al, 2007a) and NAT2 (Husain et al., 2007b), forward primer and reverse primer will be used with TaqMan probe.

\section{NAT1 Genotyping}

DNA will be extracted from human fibroblast cell samples using the "Qiagen DNA Purification kit" (Qiagen, Valencia. CA). NAT1 genotype will be determined as previously described (Doll and Hein, 2002). Briefly, NAT1 amplification will be carried out in an Applied Biosystems StepOnePlus Real-Time PCR Systems with two initial hold steps $\left(50^{\circ} \mathrm{C}\right.$ for $2 \mathrm{~min}$., followed by $95^{\circ} \mathrm{C}$ for $10 \mathrm{~min}$.) and 40 thermocycles of a two-step PCR: $92^{\circ} \mathrm{C}$ for $15 \mathrm{~s}, 60^{\circ} \mathrm{C}$ for $1 \mathrm{~min}$. The fluorescence intensity of each sample will be measured at temperature change to monitor amplification of the NAT1 gene. Controls are run to ensure that contaminated 
DNA is not amplified. Primers, probes, and DNA are added to final concentrations of $300 \mathrm{nM}, 100 \mathrm{nM}$, and $0.5-2.5 \mathrm{ng} / \mu \mathrm{l}$, respectively

Aim 2: To evaluate and compare the effects of combinations of genetic variants in NAT2 (i.e. rapid or slow phenotypes) and high and low NAT1 and CYP1A2 enzymatic activities on oxidative stress, DNA adduct formation, and mutagenesis. We hypothesize that cell lines with combinations of altered enzymatic activity associated with slow acetylator (NAT) and rapid hydroxylation (CYP) will present an increased incidence of oxidative DNA damage, while cell lines with rapid acetylator (NAT) and slow hydroxylation (CYP) will exhibit less oxidative DNA damage, but increased incidences of DNA adduct formation and mutagenesis.

\section{NAT1 and CYP1A2 gene knockdown by RNA interference}

We will utilize Dharmacon SMART pool siRNA (Thermofisher) formatted to target the open reading frame of human CYP1A2 and the 3' untranslated region (3'UTR) of human NAT1 mRNA to achieve knock down of the expression of CYP1A2 and NAT1. SMART pool siRNA products contain four highly functional duplexes that target different regions of the target gene, guaranteeing $75 \%$ knockdown of genes. The open reading frame region of CYP1A2 will be targeted because only the complete coding region sequence of CYP1A2 is present in the pIRES plasmids used for initial transfection. The 3' UTR of NAT1 will be targeted 
because the cell lines also express human NAT2, and the vast difference between the 3'UTRs of both isozymes will prevent targeting of both NAT genes. The siRNA transient transfection will be achieved according to manufacturer's instructions. GM4429 cells will be seeded 48 hours before the transfection at $3 \times 10^{4}$ cells/well in order to have $60-70 \%$ confluency at the day of transfection. In a microcentrifuge tube $20 \mu \mathrm{M}$ siRNA will be mixed with $25 \mu \mathrm{l}$ of siRNA diluents and $10 \mu \mathrm{l}$ serum-free medium. In another tube, $5 \mu \mathrm{l}$ of transfection reagent will be diluted with $25 \mu \mathrm{l}$ serum-free medium. The two tubes will be mixed and incubated for 15 minutes at room temperature. The mixture will be added to a 6 well plate, which will contain $930 \mu$ l of serum-free medium. After incubating the mixture for 3-4 hours, the medium will be changed. Seventy-two hours after the application of the smart pool, the cells will be harvested for QRT-PCR to evaluate the levels of knockdown. Enzymatic activity will be measured using functional assays for NAT (HPLC) and CYP (EROD assay) as earlier described to initially test transfection efficacy.

Evaluation of the Effect of Altered Enzymatic Activity and Genetic Variance on Toxicological Outcomes

Cell lines with combinations of CYP1A2 and/or NAT1 knock down and variant NAT2 alleles will be used to evaluate the effects of altered enzymatic activity of expressed XMEs on toxicological risk. Newly generated cell lines will be treated with arylamine genotoxins and toxicological outcomes will be measured as described below. 


\section{Oxidative DNA Damage}

Oxidative DNA damage will be evaluated by enzyme immunoassay (EIA) to measure 8-hydroxy-2-deoxyguanosine (8-OH-dG), according to the manufacturer's instructions (Cayman Chemical Company, Ann Arbor, MI) . Cell lysates will be collected and DNA will be purified and digested (Qiagen) according to manufacturer's instructions. Fifty $\mu$ l of sample will be applied to a 96 well plate containing $100 \mu \mathrm{l}$ of EIA buffer or $50 \mu \mathrm{l}$ of $8-\mathrm{OH}-\mathrm{dG}$ EIA standard. Fifty $\mu \mathrm{l}$ of $8-\mathrm{OH}-\mathrm{dG}$ acetylcholinesterase tracer will be added to each well except the total activity and blank wells, followed by $50 \mu \mathrm{l}$ of $8-\mathrm{OH}-\mathrm{dG}$ EIA monoclonal antibody. The plate will be covered and incubated for $18 \mathrm{hr}$ at $4^{\circ} \mathrm{C}$. Two hundred $\mu \mathrm{l}$ of reconstituted Ellman's reagent will be added to each well and $5 \mu \mathrm{l}$ of tracer to the total activity wells. The plate will be read by Spectra Max Gemini XS plate reader (Molecular Devices, Sunnyvale, CA) at a wavelength between 405 and $420 \mathrm{~nm}$ and 8-OH-dG concentration will be quantified.

\section{DNA Isolation and DNA Adduct Quantitation}

DNA adduct levels will be measured as previously described in our laboratory (Metry et al., 2007). DNA will be isolated from cells grown in $15 \mathrm{~cm}$ plates and treated with ABP, AF, 2,6-DMA, 3,5-DMA, or 3-EA. Our laboratory has extensive experience with ABP adduct level measurement studies in other cell lines, therefore ABP will be used as a positive control in the present study. Cells will be harvested after $48 \mathrm{hr}$ and the pellet suspended in $500 \mu \mathrm{l}$ of $50 \mathrm{mM}$ Tris $\mathrm{HCl}$ and 
$10 \mathrm{mM}$ EDTA. Cells will be incubated in $50 \mu \mathrm{l}$ of $10 \%$ SDS and $20 \mu \mathrm{g} / \mathrm{ml}$ proteinase $\mathrm{K}$ for $45 \mathrm{~min}$ at $37^{\circ} \mathrm{C}$. DNA will be extracted by phenol:chloroform:isoanyl alcohol (25:24:1) and precipitated using cold isopropanol and centrifuged for $1 \mathrm{~min}$. Supernatant will be removed and the pellet washed with ethanol, dried, and resuspended in buffer containing $5 \mathrm{mM}$ Tris $\mathrm{HCl}, 1 \mathrm{mM} \mathrm{CaCl}_{2}, 1 \mathrm{mM} \mathrm{MgCl}_{2}$, and $1 \mathrm{mM} \mathrm{ZnCl}_{2}$. DNA will be quantified at $\mathrm{A}_{260}$. DNA samples will be treated with 10 units DNAase I (US Biological, Swampscott, MA) for 1 hour at $37^{\circ} \mathrm{C}$ and nuclease P1 (US Biological) for six hours, followed by overnight treatment with 5 units of alkaline phosphatase (Sigma). Two volumes of acetonitrile will be added to stop the reaction. Samples will be filtered using a 5,000 nominal molecular weight limit centrifugal filter device (Millipore, Bedford, MA) and will be evaporated to $50 \mu \mathrm{L}$. Samples will then be reconstituted in $5 \%$ acetonitrile to a final volume of $100 \mu \mathrm{L}$. Samples will be used for LC-MS-MS analysis performed by Biomolecular Mass Spectrometry laboratory of Dr. William Pierce. Samples used for quantitative analysis will be spiked with one ng deuterated internal standard before any sample treatment. Samples will be loaded into the Inertsil C18 precolumn using Perkin Elmer ABI 140D syringe pumps and a Hewlett Packard 1100 Series Autosampler. Samples will be injected into a Micromass Quattro LC triple quadrupole mass spectrometer using nanospray with $20 \mu \mathrm{m}$ i.d. fused silica tubing inserted through $125 \mu \mathrm{m}$ i.d. PEEK tubing as previously described (Neale et al., 2008). 


\section{Assays for Mutagenesis at the hprt Locus}

To evaluate mutagenesis at the hprt locus we will employ methods previously used in our lab (Metry et al., 2007). Cells will be grown for 12 doublings, with selective agents in complete HAT medium (30 $\mu \mathrm{M}$ hypoxanthine, $0.1 \mu \mathrm{M}$ aminopterin, and $30 \mu \mathrm{M}$ thymidine). Survival will be determined by colony forming assay and expressed as percent of vehicle control. The remaining cells will be re-plated and sub-cultured. After 7 days of growth, cultures will be plated for cloning efficiency in complete media and for mutations in complete medium containing $40 \mu \mathrm{M}$ 6-thioguanine (6-TG) (Sigma). Dishes will be seeded with $1 \mathrm{x}$ $10^{5}$ cells $/ 100 \mathrm{~mm}$ and incubated for 7 days; cloning efficiency dishes will be seeded with 100 cells/ well/ 6-well plate and incubated for 6 days. In order to distinguish between effects of DNA damage by activated arylamine versus oxidative damage we will employ a $\mathrm{Cu}(\mathrm{II})$ specific chelator, bathocuproine, to ablate mutagenesis occurring as a result of oxidative damage.

Aim 3: To determine the effectiveness of a novel arylamine NAT1 small molecule inhibitor on reducing mutagenesis and DNA adduct formation. We hypothesize that the inhibition of NAT1 enzymatic activity will reduce mutagenesis and DNA adduct formation, but increase oxidative DNA damage.

In order to identify novel inhibitors of NAT a two-stage screening process will be utilized. The first stage included previous studies by Dr. John Trent, University of Louisville, that identified approximately 150 NAT inhibitor candidates by computer-based in silico screening of approximately 20 million compounds. 
Initial screening of inhibitory properties of the candidate compounds will be evaluated using NAT1 (PABA)- and NAT2 (SMZ)- specific enzymatic assays that recombinantly express human NAT1 or NAT2 in yeast. Reactions will be prepared with acetyl- coenzyme A (1 mM), selective substrates p-aminobenzoic acid (NAT1) or sulphamethazine (NAT2) $(300 \mu \mathrm{M})$, and potential inhibitors at varying concentrations between $0-1 \mathrm{mM}$. Control reactions will substitute the vehicle (DMSO) for inhibitor. The reactions will be stopped using $1 \mathrm{M}$ acetic acid and protein will be centrifuged at $10,000 \times \mathrm{g}$ for 10 minutes. Reaction products in the resulting supernatant will be separated by reverse-phase HPLC as previously described. We will evaluate the effectiveness of promising inhibitors on reducing mutagenesis and DNA adduct formation. Cells will be treated with varying doses of inhibitor, followed by measurements of oxidative damage, hprt mutagenesis, and DNA adduct levels as described above. $I_{50}$ values of the most promising NAT1 inhibitors will be determined by evaluating the inhibition of ABP, PABA, and SMZ N-acetylation activity in lysates of yeast that recombinantly express human NAT1 or NAT2. Activity will be determined using $100 \mu \mathrm{M}$ acetyl CoA and $10 \mu \mathrm{M}$ ABP, PABA, or SMZ with varying concentrations of inhibitor $(0-100 \mu \mathrm{M})$. Screening of additional compounds will be completed to determine their ability to inhibit NAT.

\section{Statistical Analysis}

Quantitative analysis of differences between various test groups will be done using one-way analysis of variance (ANOVA), with the Bonferroni posttest. We 
will use the Student's $t$ test to compare differences between an experimental group and a control group. 


\section{CHAPTER IV}

\section{RESULTS AND DISCUSSION}

We have successfully constructed NER-deficient SV40- transformed human fibroblast cells that stably express human NAT2 alleles (NAT2*4, $N A T 22^{*} 5 B$, or $N A T 2^{\star} 7 B$ ) and human CYP1A2. This was accomplished using the Flp-In system (Invitrogen, Carlsbad, CA). The CYP1A2-, CYP1A2/NAT2*4-, CYP1A2/NAT2*5B and CYP1A2/NAT2*7B- transfected cells exhibited EROD when assessed using fluorimetric determination of 7-ethoxyresorufin oxidation. No statistical differences $(p>0.05)$ in CYP1A2 EROD catalytic activity were observed between GM4429/CYP1A2 cells and the cell lines further transfected with NAT2 alleles (Figure 3.).

Human NAT2-specific SMZ N-acetylation activity was measured to validate successful production of stable transformants expressing NAT2*4, $N A T 2{ }^{\star} 5 \mathrm{~B}$ and $N A T 2^{\star} 7 \mathrm{~B}$ (Figure 4.). All NAT2 transfected cells had significantly higher SMZ N-acetylation activity than the non-transfected cell lines. Lysates collected from cells transfected with $N A T 2^{*} 5 \mathrm{~B}$ and $N A T 2^{\star} 7 \mathrm{~B}$ showed significantly lower SMZ N-acetylation activity when compared to the reference allele NAT2*4 using one-way ANOVA analysis followed by Bonferroni posttest $(p<0.001)$. Activity in GM4429 cells not transfected with NAT2 were below the level of detection for SMZ N-acetyltransferase $(<0.15 \mathrm{nmoles} / \mathrm{min} / \mathrm{mg})$. 
As shown in Figure 5., cells were tested for PABA $\mathrm{N}$-acetyltransferase activity in lysates of NER-deficient SV40 transformed GM4429 cells stably transfected with human CYP1A2 and human NAT2 alleles. No significant difference in PABA $\mathrm{N}$-acetylation activity was observed among all GM4429 cells lines using one-way ANOVA analysis ( $p>0.05)$.

The identification of NAT inhibitors in a two stage screening method is previously described. Based on our intial in vitro screening we determined that the compound ethyl[1-(3-ethoxycarbonylpropanoyloxy)-10-dioxo-2-anthryl]butanedioate (compound 10) was most promising in its ability to inhibit acetylation activity (Table 1.). Compound 10 inhibition of PABA and ABP $N$ acetylation activity in lysates of yeast that recombinantly express human $N A T 1^{*} 4$ was determined to be $100 \%$ (Figure 6.). $I \mathrm{CC}_{50}$ values were calculated and determined to be $0.75 \mu \mathrm{M}(\mathrm{PABA})$ and $0.97 \mu \mathrm{M}(\mathrm{ABP})$ in yeast lysate that recombinantly express human $N A T 1^{*} 4$ (Figure 6.). In yeast lysate that recombinantly express human $N A T 2^{*} 4 I_{50}$ values were determined to be 41.3 $\mu \mathrm{M}(\mathrm{ABP})$ and $82.2 \mu \mathrm{M}(\mathrm{SMZ})$ (Figure 7.). In $\mathrm{CHO}$ cells stably transfected with human $N A T 1^{*} 4 I_{50}$ values for compound 10 were determined to be $8 \mu \mathrm{M}$ (ABP) and $118 \mu \mathrm{M}$ (PABA) (Figure 8.). 


\section{DISCUSSION}

Our results show that we have successfully constructed and characterized NER-deficient human fibroblast cell lines that stably express human NAT2 alleles (NAT2*4, NAT2*5B, or NAT 2*7B) and CYP1A2. These cell lines can be used to study NAT metabolism. Future studies include the investigation of functional effects of genetic variations in NAT2, in the presence of human NAT1, on arylamine metabolism and toxicological risk. The cell lines used in this study are most beneficial because they endogenously express human NAT1, therefore are practical in studying not only substrate specificity, but combinations of altered enzymatic activity in human CYP1A2, human NAT1 and genetic variance in human NAT2.

This study also introduces the use of novel small molecule NAT1 inhibitors to reduce DNA adduct formation and mutagenesis. The applications of these compounds are novel. We expect that inhibiting NAT1 catalytic activity will reduce mutagenesis and DNA adduct formation resulting from NAT1 $O$ acetylation. We expect to see an increase in oxidative stress because inhibition of NAT activity will increase substrate availability for metabolic hydroxylation leading to an increased production of reactive oxygen species, consequently increasing oxidative DNA damage. The results of this investigation provide insight into functional genomic studies of NAT2 in human cells. We expect that 
future studies will allow us to determine more details of the relationship between genetic variations and toxicological risk from genotoxic environmental arylamines. 


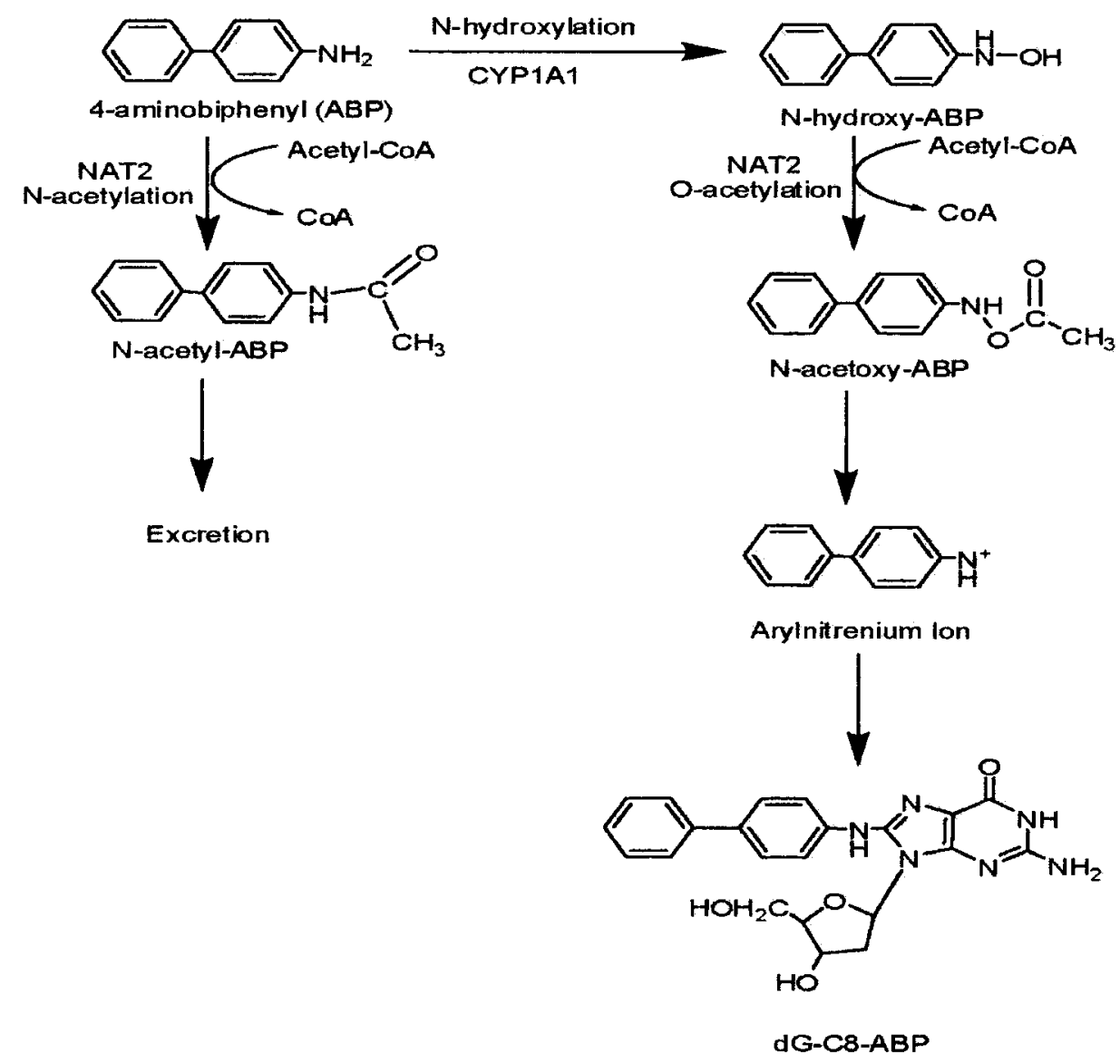

Figure 1. Metabolic pathways of 4-aminobiphenyl by NAT.

Adapted from Bendaly et al., 2009. 

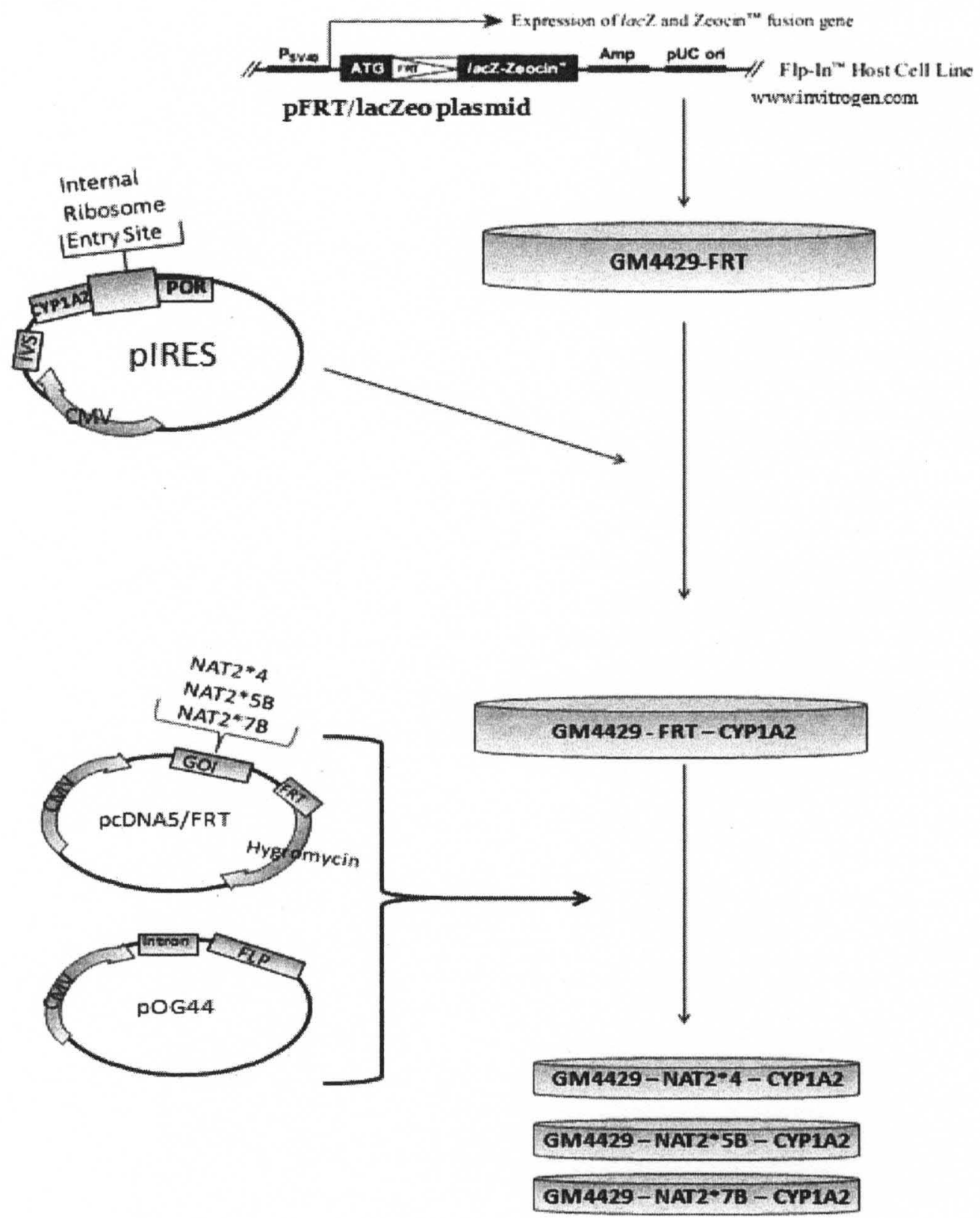

Figure 2. Schematic of stable transfection using the Invitrogen Flp-In System 


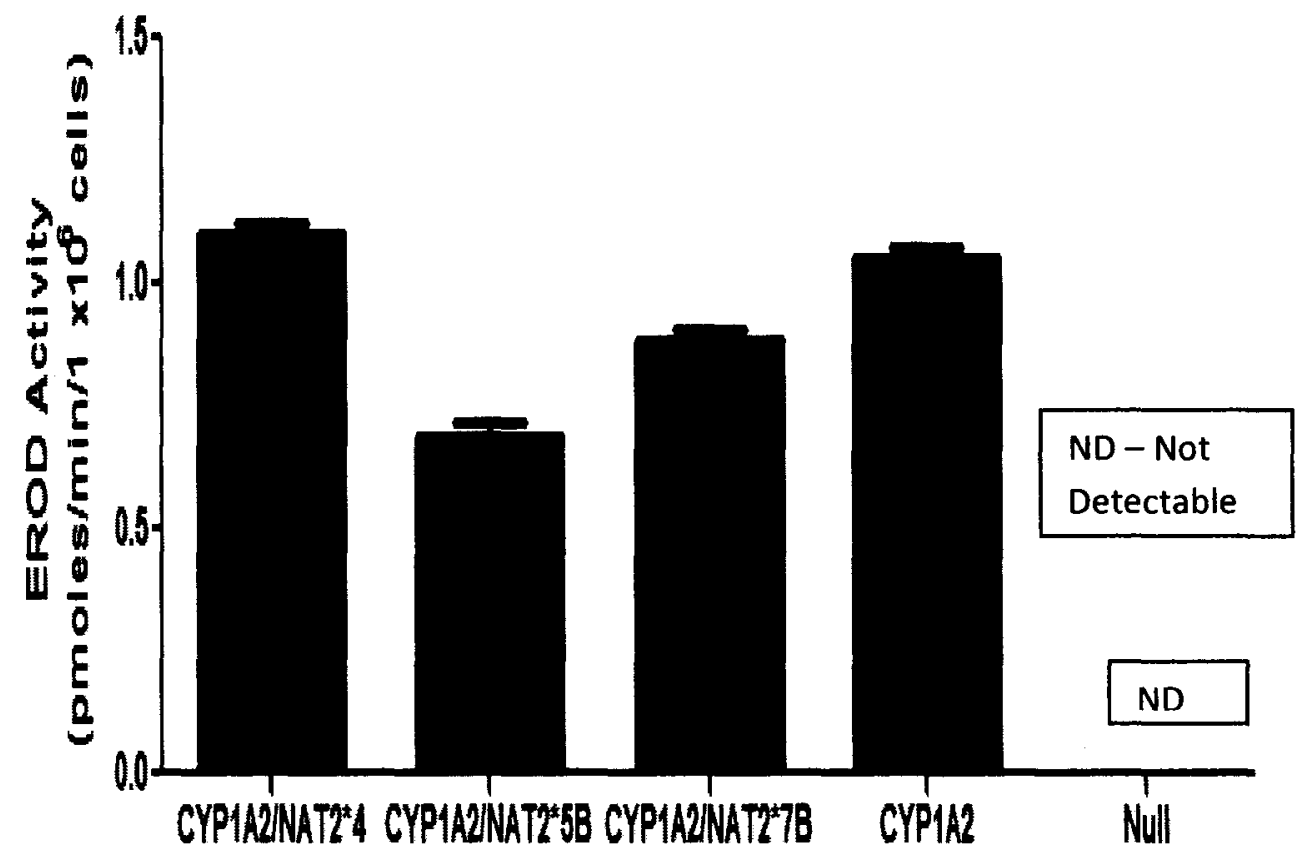

Figure 3. CYP1A2 EROD activity in NER-Defiecient SV40-transformed GM4429 cells. Each bar represents mean \pm SEM for 3 experiments determining 7 ethoxyresorufin-O-deethylase (EROD) activity (pmoles $/ \mathrm{min} / 1 \times 10^{6} \mathrm{cells}$ ) in NERdeficient SV40-transformed GM4429 cells stably transfected with human CYP1A2 and human NAT2 alleles. No significant difference in EROD activity was observed among transfected cells using one-way ANOVA analysis $(p>0.05)$ EROD activity in non-transfected cells was below the limit of detection $(<0.05$ pmoles $/ \mathrm{min} / 1 \times 10^{6}$ cells). 


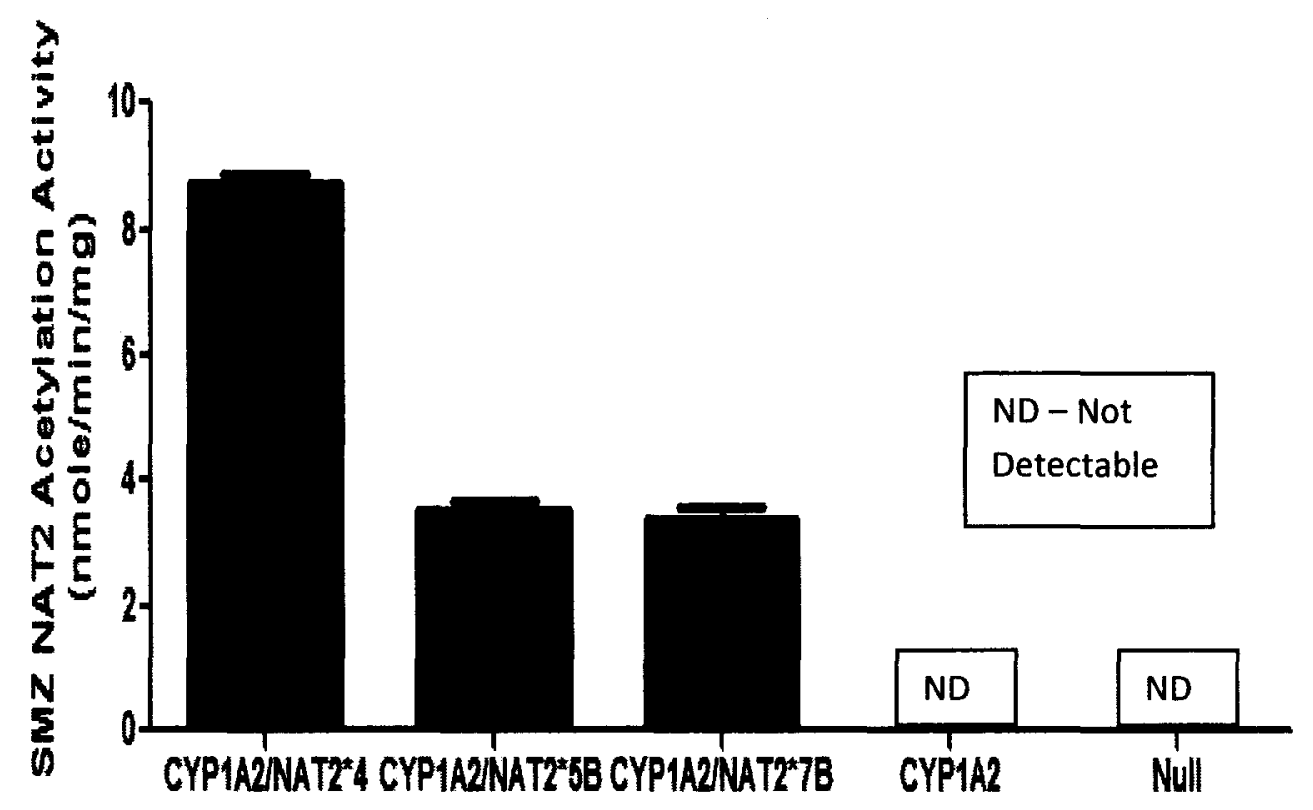

Figure 4. SMZ N-acetyltransferase activity in cell lysates of NER-deficient SV40transformed GM4429 cells stably transfected with human CYP1A2 and human NAT2 alleles. All NAT-transfected cells had significantly higher SMZ Nacetylation activity than the non-transfected cells. Lysates collected from cells transfected with NAT2*5B and NAT2*7B showed significantly lower SMZ Nacetylation activity when compared to extracts of cells transfected with the reference allele NAT2*4 using one-way ANOVA analysis followed by Bonferroni posttest $(p<0.001)$. SMZ $N$-acetyltransferase activity of non-transfected GM4429 cells was below the level of detection ( $<0.15 \mathrm{nmoles} / \mathrm{min} / \mathrm{mg}$ protein). 


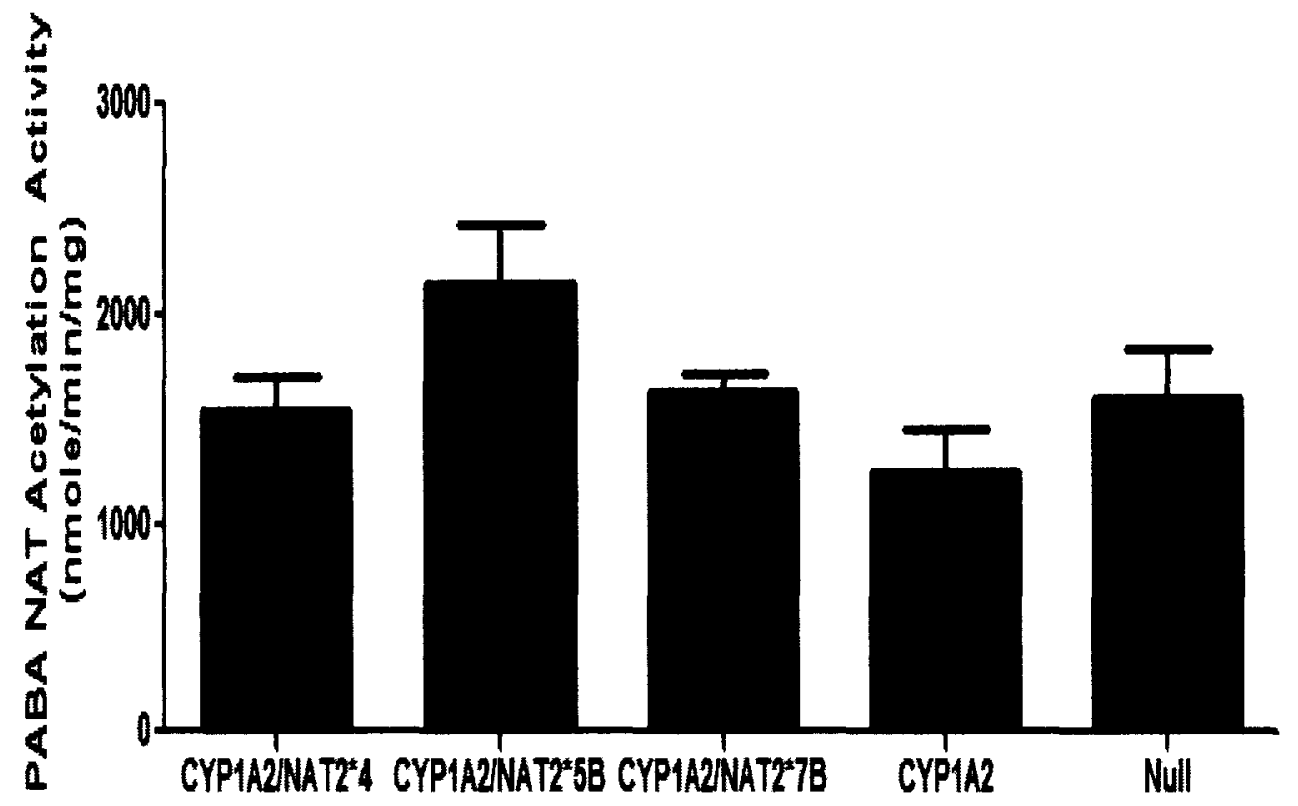

Figure 5. PABA $N$-acetyltransferase activity in cell lysates of NER-deficient SV40 transformed GM4429 cells stably transfected with human CYP1A2 and human NAT2 alleles. PABA $N$-acetylation was determined with $1 \mathrm{mM}$ acetyl $\mathrm{CoA}$ and $300 \mu \mathrm{M}$ PABA. No significant difference in PABA $N$-acetylation was observed among all GM4429 cells lines using one-way ANOVA analysis ( $p>0.05)$. 


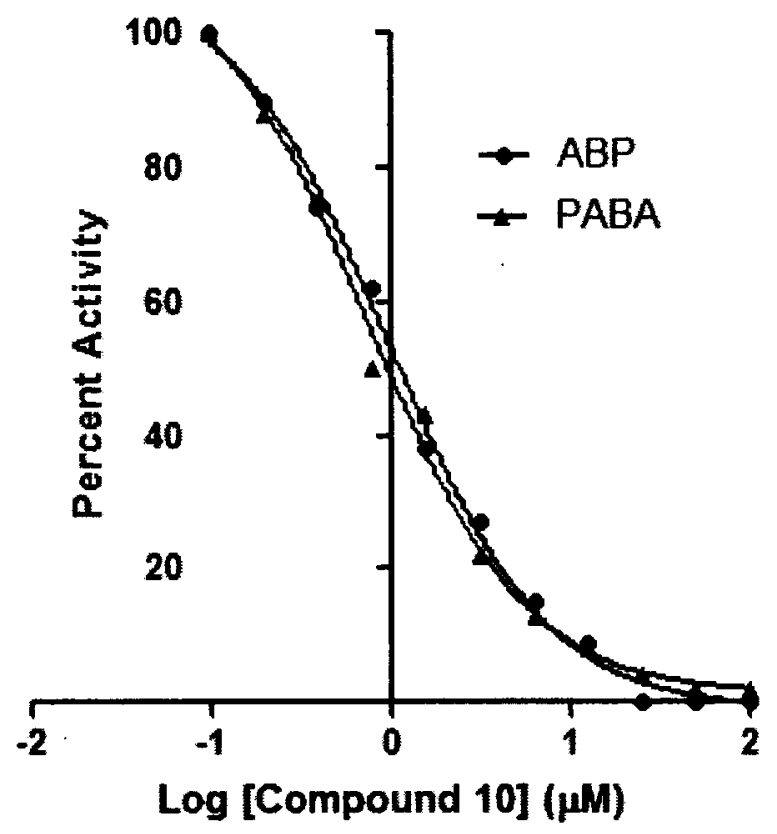

Figure 6. Compound 10 inhibition of PABA and $A B P N$-acetylation activity in lysates of yeast that recombinantly express human NAT1. Each point represents mean \pm SEM for 3 experiments determining compound 10 inhibition of PABA and $A B P \mathrm{~N}$-acetylation activity in lysates of yeast that recombinantly express human NAT1. 


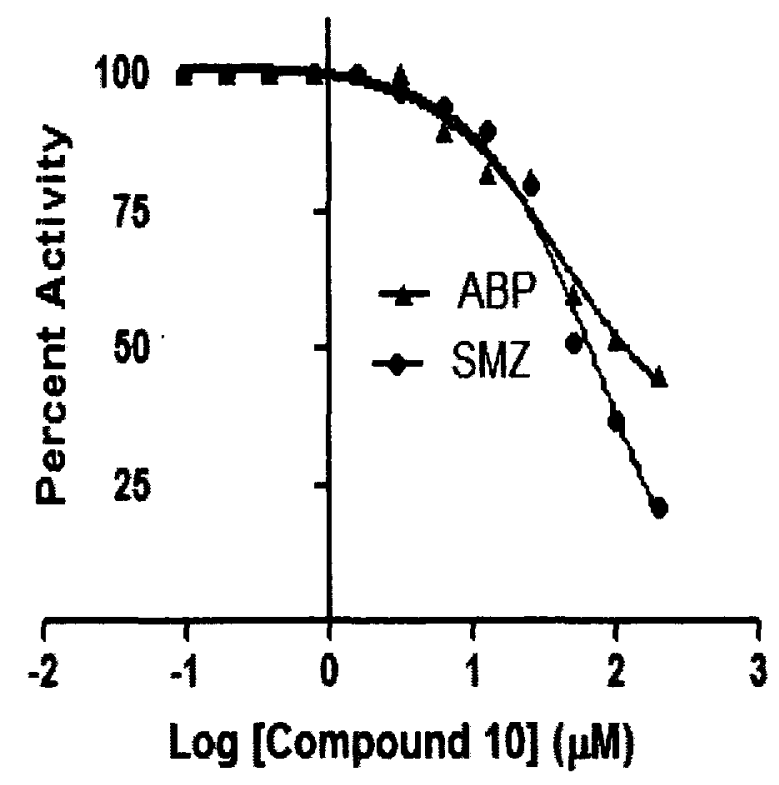

Figure 7. Compound 10 inhibition of $A B P$ and $S M Z N$-acetylation activity in lysates of yeast that recombinantly express human NAT2. Each point represents mean \pm SEM for 3 experiments determining compound 10 inhibition of ABP and SMZ $N$-acetylation activity in lysates of yeast that recombinantly express human NAT2. 


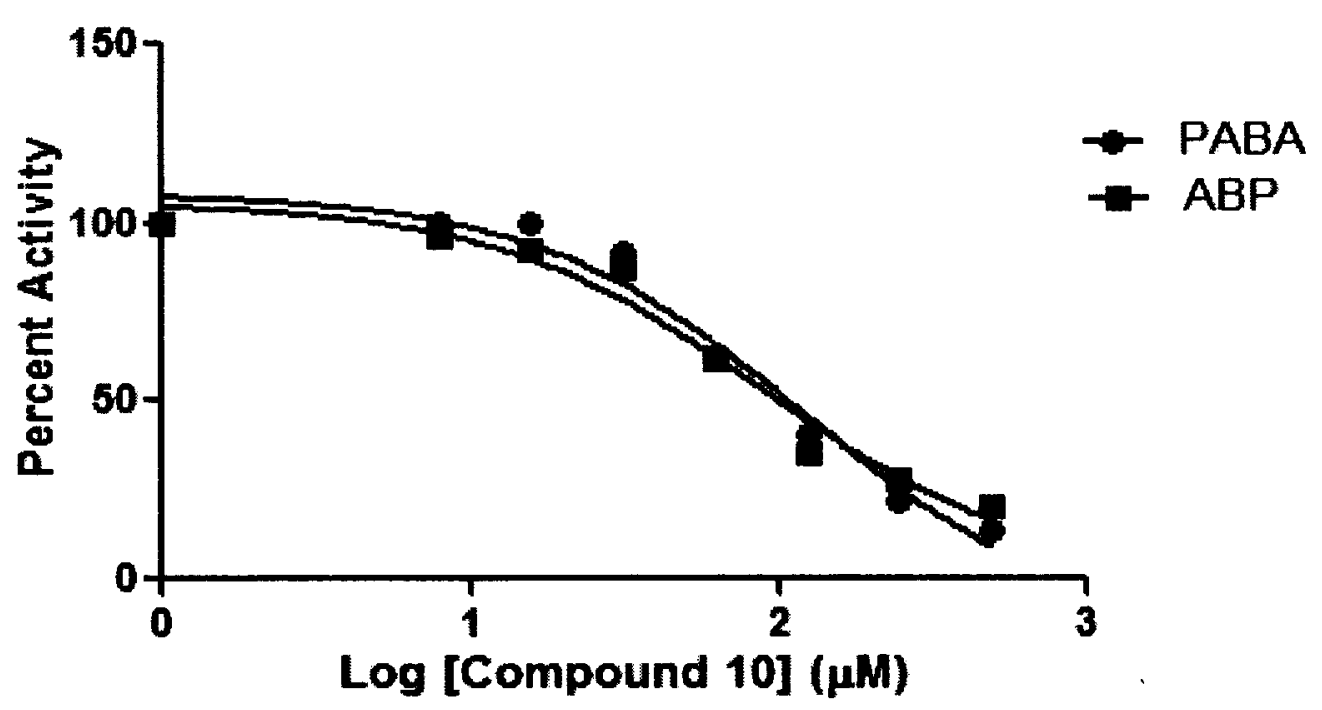

Figure 8. Compound 10 inhibition of $A B P$ and PABA $N$-acetylation activity in $\mathrm{CHO}$ cells that recombinantly express human NAT1. Each point represents mean \pm SEM for 3 experiments determining compound 10 inhibition of $A B P$ and PABA $\mathrm{N}$-acetylation activity in $\mathrm{CHO}$ cells that recombinantly express human NAT1. 


\section{REFERENCES}

Agudo, A., Peluso, M., Sala, N., Capella, G., Munnia, A., Piro, S., Tormo, M., Ardanaz, E., Barricarte, A., Chiralaque, M., Dorronsoro, M., Larranaga, N., Martinez, C., Navarro, Quiros, J., sanchez, M., and Gonzalez, C. (2009) Aromatic DNA adducts and polymorphisms in metabolic genes in healthy adults: findings from the EPIC-Spain cohort. Carcinogenesis 30, 968-976.

Bendaly, J., Zhao, S., Neale, J.R., Metry, K.J., Doll, M.A., States, J.C., Pierce, W.M., Jr., and Hein, D.W. (2007). 2-Amino-3,8-dimethylimidazo-[4,5f]quinoxaline-induced DNA adduct formation andmutagenesis in DNA repairdeficient Chinese hamster ovary cells expressing human cytochrome P4501A1 and rapid or slow acetylator $\mathrm{N}$-acetyltransferase 2. Cancer Epidemiology Biomarkers and Prevention 16, 1503-1509.

Butcher, N. J., Ilett, K. F, and Minchin, R. F. (1999) Substrate-dependent regulation of human arylamine $\mathrm{N}$-acetyltransferase- 1 in cultured cells. Molecular Pharmacology 57, 468-473.

Cascorbi, I., Roots, I., Brockmoller, J. (2001) Association of NAT1 and NAT2 polymorphisms to urinary bladder cancer: significantly reduced risk in subjects with NAT1*10. Cancer Research 61, 5051- 5056.

Dairou, J., Malecazze, F., Dupret, J., and Rodrigues-Lima, Fernando. (2005). The xenobiotic-metabolizing enzymes arylamine $N$-acetyltransferase in human 
lens in epithelial cells: inactivation by cellular oxidants and UVB-induced oxidative stress. Molecular Pharmacology 67, 1299-1306.

Dairou, J., Petit, E., Ragunathan, N., Baeza-Squiban, A., Marano, F., Dupret, J.,and Rodrigues-Lima, F. (2009) Arylamine $\mathrm{N}$-acetyltransferase activity in bronchial epithelial cells and its inhibition by cellular oxidants. Toxicology and Applied Pharmacology 236, 366-371.

Doll, M. and Hein, D.W. (2002) Rapid gentype method to distinguish frequent and/or functional polymorphisms in human $N$-acetyltransferase-1. Analytical Biochemistry 301, 328-332.

Ferguson, R.J., Doll, M.A., Rustan, T.D., and Hein, D.W. (1996) Cloning, expression, and functional characterization of rapid and slow acetylation polymorphic $\mathrm{N}$-acetyltransferase encoding genes of the Syrian hamster. Pharmacogenetics 6, 55-56.

Fretland, A., Doll, M. A., Leff, M.A., and Hein, D.W. (2001) Functional characterization of nucleotide polymorphisms in the coding region of $\mathrm{N}$ acetyltranferase 1. Pharmacogenetics 6, 511-520.

Gan, J., Skipper, P.L., Gago-Dominduez, M., Arakawa, K., Ross, and R.K., Tannenbaum, S. (2004). Alkylaniline-hemoglobin adducts and risk of nonsmoking-related bladder cancer. Journal of National Cancer Institute 96, 14251431. 
Grant, D., Blum, M., Beer, M., and Meyer, U. (1990) Monomorphic and polymorphic human $\mathrm{N}$-acetyltransferases: a comparison of liver Isozymes and expressed products of two cloned genes. Molecular Pharmacology 39, 184-191.

Hein, D.W., Doll, M.A., Fretland, A. J., Leff, M.A., Webb, S.J., Xiao, G., Devanaboyina, U., Nangju, N., and Feng, Y. (2000) Molecular genetics and epidemiology of the NAT1 and NAT2 acetylation polymorphisms. Cancer Epidemiology, Biomarkers, and Prevention 9, 29-42.

Hein, D.W., Leff, M., Ishibe, N., Sinha, R., Frazier, H., Doll, M., Xiao, G., Weinrich, M., and Caporaso, N. (2002) Association of prostate cancer with rapid $\mathrm{N}$-acetyltransferase $1\left(\mathrm{NAT}^{*}{ }^{10}\right)$ in combination with slow $\mathrm{N}$-acetyltransferase 2 acetylator genotypes in a pilot case-control study. Environmental and Molecular Mutagenesis 40, 161-167.

Hein, D.W. (2009) N-acetyltranferase SNPs: emerging concepts serve as a paradigm for understanding complexities of personalized medicine. Expert Opinion Drug Metabolism Toxicology 4, 353-366.

Husain, A., Zhang, X., Doll, M.A., States, J.C., Barker, D.F., and Hein, D.W. (2007a). Functional analysis of the human $\mathrm{N}$-acetyltransferase 1 major promoter: quantitation of tissue expression and identification of critical sequence elements. Drug Metabolism and Disposition 35, 1649-1656.

Husain, A., Zhang, X., Doll, M.A., States, J.C., Barker, D.F., and Hein, D.W. (2007b). Identification of $\mathrm{N}$-acetyltransferase 2 (NAT2) transcription start sites 
and quantification of NAT2-specific mRNA in human tissues. Drug Metabolism and Disposition 35, 721-727.

Kim, Y., Lee, C., Nan, H., Kang, J., and Kim, H. Effects of genetic polymorphisms in metabolic enzymes on the relationships between 8-hydroxydeoxyguanosine levels in human leukocytes and urinary 1-hydroxypyrene and 2-naphthol concentrations. Journal of Occupational Medicine 45, 160-167.

Liu, L., Wagner, C., and Hanna, P. (2008) Human arylamine $N$ acetyltransferase 1: in vitro and intracellular inactivation by nitrosoarene metabolites of toxic and carcinogenic arylamines. Chemical Research in Toxicology 21, 2005-2016.

Lodovici, M., Casalini, C., Cariaggi, R., Michelucci, L., and Dolara, P. (2000) Levels of 8-hydroxydeoxyguanosine as a marker of DNA damage in human leukocytes. Free Radical Biology and Medicine 28, 13-17.

Martin, S., Bishop, F., Kerr, B., Moor, K., Moore, M., Sheffels, P., Rashed, M., Slatter, J., Berthon-Cedille, L., Lepage, F., Descombe, J., Picard, M., Baillie, T., and Levy, Rene. Pharmacokinetics and metabolism of the novel anticonvulsant agent $N-(2,6$-Dimethylphenyl)-5-Methyl-3-Isoxazolecarboxamide (D2624) in rats and humans. Drug Metabolism and Disposition 25, 40-46.

Metry, K.J., Zhao, S., Neale, J.R., Doll, M.A., States, J.C., McGregor, W.G., Pierce, W.M., Jr., and Hein, D.W. (2007). 2-amino-1-methyl-6-phenylimidazo [4,5-b] pyridine-induced DNA adducts and genotoxicity in Chinese hamster ovary 
$(\mathrm{CHO})$ cells expressing human CYP1A2 and rapid or slow acetylator $\mathrm{N}$ acetyltransferase 2. Molecular Carcinogenesis 46, 553-563.

Murata, M., Kobayashi, M., and Kawanishi, S. (1999) Nonenzyme reduction of nitro derivative of a heterocyclic amine IQ by NADH and $\mathrm{Cu}$ (II) leads to oxidative DNA damage. Biochemistry 38, 7624-7629.

Murata, M., Tamura, A., Tada, M., and Kawanishi. (2001). Mechanism of oxidative DNA damage induced by carcinogenic 4-aminobiphenyl. Free Radical Biology and Medicine 30, $765-773$.

Russell, A., Westwood, I., Crawford, M., Robinson, J., Kawamura, A., Redfield, C., Laurieri, N., Lowe, E., Davies, S., and Sim, E. (2009) Selective small molecule inhibitors of the potential breast cancer marker, human arylamine $\mathrm{N}$ acetyltransferase 1 , and its murine homologue, mouse arylamine $N$ acetyltransferase 2. Bioorganic and Medicinal Chemistry 17, 905-918.

Sanderson, S., Salanti, G., and Higgins, J. (2007) Joint effects of Nacetyltransferase 1 and 2 (NAT1 and NAT2) genes and smoking in bladder carcinogenesis: a literature-based systematic HuGE review and evidence synthesis. American Journal of Epidemiology 166, 741- 751. 
Skipper, P., Kim, M.Y., Sun, H.L., Wogan, G.N., and Tannenbaum, S.R. (2010). Monocyclic aromatic amines as potential human carcinogens: old is new again. Carcinogenesis 31, 50-58.

Sova, H., Jukkola-Vuorinen, A., Puistola, U., and Karihtala, P. (2010) 8Hydroxydeoxyguanosine: a new potential independent prognostic factor in breast cancer. British Journal of Cancer 102, 1018-1023.

Stanley, L., Coroneos, E.,Cuff, R., Hickman, D., Ward, A., and Sim, E. (1996) Immunochemical detection of arylamine $\mathrm{N}$-acetylatransferase in normal and neoplastic bladder. The Journal of Histochemistry and Cytochemistry 44, 10591067.

States, J.C. and Myrand, S.P. (1996) Splice site mutations in xeroderma pigmentosum group A patient with delayed onset of neurological disease. Mutation Research 363, 171-177.

States, J. C., Reiner, J. J., Pounds, J.G., Kaplan, D., Beauerle, B., McNeely, S.C., Mathieu, P., and McCabe Jr., M.J. (2002) Arsenite disrupts mitosis and induces apoptosis in SV40-transformed human skin fibroblasts. Toxicology and Applied Pharmacology 180, 83-91.

Sugamori,K.S., Brenneman,D., and Grant,D.M. (2006) In vivo and in vitro metabolism of arylamine procarcinogens in acetyltransferase-deficient mice. Drug Metabolism and Disposition 34, 1697-1702. 
Tanaka, T., Kondo,S., Iwasa,Y., Hiai, H. and Toyokun, S. ( 2000) Expression of stress response and cell proliferation genes in renal cell carcinoma induced by oxidative stress. American Journal of Pathology 156, 2149-2157.

Taylor, J.A., Umbach, D.M., Stephens, E., Castranio, T., Paulson, D., Robertson, C., Mohler, J.L., Bell, D. (1998). The role of $\mathrm{N}$-acetylation polymorphisms in smoking-associated bladder cancer evidence of a gene-gene exposure threeway interaction. Cancer Research 3603-3610.

Wells, P., McCallum, G., Lam, K., Henderson, J., and Ondovcik, S. (2010) Oxidative DNA damage and repair in teratogenesis and neurodevelopmental deficits. Birth Defects Research 90, 103-109.

Zang, Y., Doll, M., Zhao, S., States, J.C., and Hein, D.W. (2007) Functional characterization of single-nucleotide polymorphisms and haplotypes of human $\mathrm{N}$ acetyltransferase 2. Carcinogenesis 28,1665-1671.

Zhu, Y., and Hein, D.W. (2008). Functional effects of single nucleotide polymorphisms in the coding region of human $\mathrm{N}$-acetyltransferase 1. Pharmacogenomics Journal 8, 339-348. 
Table 1. Target NAT isozyme, priority number, and percent inhibition of screened compounds

\begin{tabular}{|c|c|c|c|c|}
\hline Entry & & Priority number & $\%$ inhibition of NAT2 & $\%$ inhibition of NAT1 \\
\hline 1 & NAT2 & 6 & 4 & 0 \\
\hline 2 & NAT2 & 9 & 49 & 7 \\
\hline 4 & NAT1 & 14 & 3 & 0 \\
\hline 5 & NAT1 & 19 & 0 & 30 \\
\hline 6 & NAT2 & 7 & 7 & 0 \\
\hline 7 & NAT2 & 11 & 0 & 25 \\
\hline 8 & NAT1 & 3 & 0 & 0 \\
\hline 9 & NAT1 & 20 & 7 & 14 \\
\hline 10 & NAT1 & 23 & 100 & 100 \\
\hline 11 & NAT1 & 40 & 88 & 95 \\
\hline 12 & NAT1 & 67 & 23 & 8 \\
\hline 13 & NAT1 & & 0 & 3 \\
\hline 14 & NAT1 & & 0 & 7 \\
\hline 15 & NAT2 & 24 & 9 & 5 \\
\hline 16 & NAT2 & 23 & 5 & 75 \\
\hline 17 & NAT1 & 27 & 0 & 0 \\
\hline 18 & NAT2 & 25 & 0 & 0 \\
\hline 19 & NAT1 & 47 & 2 & 16 \\
\hline 20 & NAT2 & 28 & 2 & 16 \\
\hline 21 & NAT1 & 50 & 9 & 2 \\
\hline 23 & NAT2 & 26 & 21 & 5 \\
\hline 24 & NAT2 & 27 & 22 & 15 \\
\hline 25 & NAT2 & 30 & 37 & 2 \\
\hline 26 & NAT1 & 26 & 0 & 31 \\
\hline 27 & NAT2 & 46 & 0 & 0 \\
\hline 28 & NAT2 & 57 & 26 & 0 \\
\hline 30 & NAT1 & 49 & 7 & 0 \\
\hline 31 & NAT2 & 52 & 14 & 27 \\
\hline 32 & NAT1 & 54 & 30 & 43 \\
\hline 33 & NAT2 & 53 & 0 & 7 \\
\hline 34 & NAT2 & 33 & 10 & 14 \\
\hline 35 & NAT2 & 22 & 2 & 0 \\
\hline 36 & NAT2 & 41 & 0 & 0 \\
\hline 37 & NAT2 & 32 & 4 & 17 \\
\hline 38 & NAT2 & 60 & 13 & 21 \\
\hline 39 & NAT2 & 67 & 0 & 5 \\
\hline 40 & NAT2 & 58 & 0 & 3 \\
\hline 41 & NAT2 & 56 & 2 & 0 \\
\hline 42 & NAT2 & 49 & 0 & 14 \\
\hline 43 & NAT2 & 55 & 27 & 0 \\
\hline 44 & NAT2 & 68 & 10 & 13 \\
\hline 45 & NAT2 & 51 & 0 & 20 \\
\hline 46 & NAT2 & 38 & 15 & 21 \\
\hline 47 & NAT2 & 44 & 14 & 5 \\
\hline
\end{tabular}




\section{CURRICULUM VITAE}

\section{CARMINE SIMONE LEGGETT \\ University of Louisville School of Medicine \\ Department of Pharmacology and Toxicology \\ Louisville, KY 40202}

\section{Education}

Spelman College

Atlanta, GA

B.S. - Chemistry (May 2006)

Delaware State University

Dover, DE

M.S. - Applied Chemistry (May 2008)

University of Louisville School of Medicine

Louisville, KY

Pharmacology and Toxicology

\section{Scientific Experience and Research Positions}

Graduate Research Assistant, Department of Pharmacology and Toxicology University of Louisville School of Medicine

Louisville, KY (2008 - )

Graduate Research Assistant, BNL Medical Department

Radiotracer Chemistry and Instrumentation Biological Imaging

Graduate Research Internship Program (GRIP) Fellow

Brookhaven National Laboratory

Upton, NY (2008 - 2008)

- Radiolabeling and Validation of Precursors used to trace Cannabinoid $\left(\mathrm{CB}_{1}\right)$ receptors

- Synthesis and Labeling of SSR149415 
Model Institute for Excellence (MIE) Research Fellow

Spelman College

Atlanta, GA (2004-2006)

- Determined optimal conditions for the synthesis of the benzimidazole derivatives

- Microwave synthesis of aniline and benzimidazole derivatives

- Purification of molecules by flash chromatography and recrystallization

- Characterization by NMR and IR

- Assisted group members with various projects

- Maintained chemical stock

Alliance for Graduate Education and Professorate (AGEP)

Research Assistant

University of lowa

lowa City, IA (Summer 2005)

- Project Title: "Biotransformation of Indene by Candida Strains"

- Frozen stock was used to incubate shaker flask in order to produce a growth curve for various Candida strains

- Produced indandiol and indanoxide using strain UI-9773 which was analyzed by NMR and TLC

Multicultural Academic Opportunity Program (MAOP) Research Assistant

Virginia Polytechnic Institute and State University

Virginia Bioinformatics Institute (VBI)

Blacksburg, VA

- Participated in research: "Sequence Data Annotation of Expressed Sequence Tags of Phytophthora"

- Manually reviewed and organized singlet data

- Produced database of metabolic pathways for Phytophthora

- Created web-based data using HTML

Health Careers Opportunity Program (HCOP) Research Assistant Albany State University

Albany, GA (Summer 2002)

- Participated in research: "Utilizing Susceptibility Test to Optimize Antibiotic Therapy"

- Employed laboratory research techniques, laboratory safety, literature and database research 
Summer Science Engineering and Mathematical Institute Research Assistant Clark Atlanta University

Atlanta, GA

- Participated in enrichment coursework

- Introduced to research techniques and laboratory safety

\section{Research and Professional Organizations}

- National Organization for the Professional Advancement of Black Chemist and Chemical

Engineers (NOBCChe)

- American Chemical Society

- Black Biomedical Graduate Student Organization (vice-president 2010- , secretary 2009-2010)

\section{Honors and Awards}

- Integrated Programs in Biomedical Sciences Fellow, University of Louisville School of Medicine

- National Science Foundation Greater Philadelphia Alliance for Minority Participation Bridge to the Doctorate Fellowship, Delaware State University

- Graduate Research Internship Program (GRIP) Fellow, Brookhaven National Laboratory

- Model Institute for Excellence (MIE) Fellowship, Spelman College

- Chemistry Department Teaching Assistantship, Spelman College

- Helping Outstanding Pupils Educationally (HOPE) Scholar, Spelman College

\section{Abstracts and Presentations}

Carmine S. Leggett, David F. Barker, Mark A. Doll, Lori M. Millner, J.Christopher States, and David W. Hein. Construction and Functional Characterization of Nucleotide Excision Repair - Deficient SV40-Transformed Human Fibroblast Expressing Human CYP1A2 and NAT2 Genetic Variants. Fifth International Workshop on the Arylamine $\mathrm{N}$-acetyltransferases University of Paris Diderot. Paris, France. 2010

Carmine S. Leggett, Mark A. Doll, John O. Trent, Jason M. Walraven, Lori M. Millner, David W. Hein. Identification and Characterization of Novel Arylamine NAcetyltransferase Small Molecule Inhibitors.. University of Louisville School of Medicine Research Louisville. Louisville, KY. 2009 
Carmine Leggett, Joanna Fowler, Jacob Hooker, Alexander Makryannis, Alicia Reid, and Alexander Zvonok.: Development and Validation of $\left[{ }^{11} \mathrm{C}\right] S S R 149415$ and Indole Derivatives as PET agents for Imaging of Cannabinoid $\left(\mathrm{CB}_{1}\right)$ and Vasopressin $\left(\mathrm{V}_{1 \mathrm{~b}}\right)$ Receptors. Brookhaven National Laboratory Research Symposium. Upton,NY. 2007

Carmine Leggett, Leyte Winfield. Using ADMET Predictor to Measure Parameters of Heterocyclic Molecules. Spelman College Research Day. Atlanta, GA. 2006

Carmine Leggett, Emmanuel Ankudey, Tonya Peeples. Biotransformation of Indene by Candida strains. Alliance for Graduate Education and

Professorate Research Symposium. University of lowa. lowa City, lowa 2005.

Carmine Leggett, Erika Thomas, Leyte Winfield. Synthesis of Benzimidazole Derivatives. Model Institute of Excellence Research Day. Spelman College. Atlanta, GA. 2005.

Carmine Leggett, LaChelle Waller, Brett Tyler. Sequence Data Annotation of Expressed Sequence Tags of Phytophthora. Virginia Tech Research Symposium. Blacksburg, VA.2004

\section{Publications}

Matthias Schönberger, Carmine Leggett, Sung Won Kim, and Jacob M. Hooker. Synthesis of $\left[{ }^{11} \mathrm{C}\right]$ SSR 149415 and preliminary imaging studies using positron emission tomography. Bioorganic and Medical Chemistry Letters 15: 31033106, 2010. (Epub April 2, 2010) [PMID: 20400305]

Hein, D.W., Millner, L.M., Leggett, C.S. and Doll, M.A.: Relationship between Nacetyltransferase 2 single nucleotide polymorphisms and phenotype. Carcinogenesis 31: 326-327, 2010. (Epub November 23, 2009). [PMCID: 2812573]

Winfield, Leyte; Smith, Dayle M.; Halemano, Kalani; Leggett, Carmine S. A Preliminary Assessment of Structure- Activity Relationship of BenzimidazoleBased Anti-Proliferative Agents. Letters in Drug Design and Discovery 5: 369376, 2008. [ISSN:1570-1808] 